\title{
Evaluation of effectiveness and outcome of PKU screening and management in the State of Sergipe, Brazil
}

\author{
Avaliação da eficiência e desfecho da triagem e \\ manejo da PKU no Estado de Sergipe, Brasil
}

Antônio R. O. Ramalho', Roberto J. R. Ramalho', Carla R. P. Oliveira', Marta M. G. S. Magalhães', Elenilde G. Santos', Polyana M. P. Sarmento', Diana O. Matos', Mario C. P. Oliveira', André L. P. Oliveira', Manuel H. Aguiar-Oliveira'

1 Department of Medicine, University Hospital, Universidade Federal de Sergipe (UFS), Aracaju, SE, Brazil
Correspondence to: Manuel H. Aguiar Oliveira Rua Cláudio Batista s/n 49060-100 - Aracaju, SE, Brazil herminio@infonet.com.br

Received on July/12/2013 Accepted on Sept/10/2013

\begin{abstract}
Objectives: Phenylketonuria (PKU) was the first inherited metabolic disease known to cause mental retardation for which a newborn screening program (NBS) was developed. The objective of this study was to evaluate the effectiveness of PKU NBS and the management of cases in the northeastern Brazilian state of Sergipe (SE). Materials and methods: We reviewed the phenylalanine concentrations in filter-paper collected from the heel (PKUneo) of 43,449 newborns; blood concentrations obtained by venipuncture in the subjects with abnormal PKUneo; the children's age at several phases of the program, the incidence of the disease from January 2007 to June 2008; and metabolic control of the patients. Results: The coverage of NBS/SE was 78.93\%. The children's age was $10 \pm 7$ days at PKUneo collection. Twelve children were recalled based on the PKUneo cutoff value at $28 \pm 13$ days. From these, the concentrations of phenylalanine collected by venipuncture were normal in five children. The incidence of hyperphenylalaninemia was $1 / 43,449$, and of PKU was $1 / 8,690$ ( 5 cases). One suspected subject died. Another death occurred in the cohort, in a confirmed PKU case. PKU treatment began within $51 \pm 12$ days of life. In the four patients under dietary phenylalanine restriction, metabolic control was often difficult. Conclusions: PKU NBS/SE has satisfactory coverage and adequate cutoff for recalling patients and diagnosis, but the onset of treatment is delayed, and follow-up metabolic control is frequently inadequate. Arq Bras Endocrinol Metab. 2014;58(1):62-7
\end{abstract}

\section{Keywords}

Phenylketonuria; screening neonatal; phenylalanine; coverage; incidence

\section{RESUMO}

Objetivos: A fenilcetonúria (PKU) foi a primeira causa metabólica hereditária de retardamento mental para a qual foi desenvolvido um programa de triagem em recém-nascidos (NBS). 0 objetivo deste estudo foi avaliar a eficácia do NBS para a PKU e o manejo dos casos em Sergipe (SE), Brasil. Materiais e métodos: Revisamos as concentrações de fenilalanina no filtro de papel coletado do calcanhar (PKUneo) de 43.449 recém-nascidos, suas concentrações de sangue obtidas por punção venosa em indivíduos com PKUneo anormal, a idade das crianças em diversas fases do programa, a incidência da doença no período de janeiro de 2007 a junho de 2008 e o controle metabólico dos pacientes. Resultados: A cobertura da NBS/SE foi de 78,93\%. A idade das crianças era de $10 \pm 7$ dias na coleta de PKUneo. Doze crianças foram reconvocadas com base no ponto de corte de PKUneo aos $28 \pm 13$ dias de idade. Destas, as concentrações de fenilalanina por venipunctura foram normais em cinco. A incidência da hiperfenilalaninemia foi $1 / 43.449$ e de PKU foi 1/8.690 (5 casos), e um indivíduo suspeito foi a óbito. Outro óbito ocorreu na coorte em um caso de PKU confirmado. 0 tratamento para a PKU começou com $51 \pm 12$ dias. Nos quatro pacientes sob restrição de fenilalanina alimentar, o controle metabólico foi frequentemente difícil. Conclusões: PKU NBS/SE apresenta uma cobertura satisfatória e ponto de corte adequado para reconvocação e diagnóstico, mas o início do tratamento é atrasado e o controle no seguimento é frequentemente inadequado. Arq Bras Endocrinol Metab. 2014;58(1):62-7

\section{Descritores}

Fenilcetonúria; triagem neonatal; fenilalanina; cobertura; incidência 


\section{INTRODUCTION}

$\mathrm{P}$ henylketonuria (PKU) is an autosomal recessive disease with an incidence in Caucasian populations between 1 in 10,000 and 1 in 15,000 people $(1,2)$. It results from more than 500 different mutations in phenylalanine hydroxilase gene located on chromossome 12q. Mutations cause reduced activity of the enzyme and deficient conversion of phenylalanine to tyrosine. This causes an increase of phenylalanine (Phe) in the blood stream and body tissues, with urinary elimination of phenylpiruvic acid and variable capacity of metabolism of dietary Phe. For decades, early screening and lifetime use of low Phe diet have been recommended to avoid cerebral damage resulting in mental deficit, and motor, neurological, and behavioral problems. Despite this, cognitive performance is still suboptimal in most series (1,3-9), and studies with magnetic resonance imaging have shown white matter lesions in the brain of adult PKU patients, which are directly related with blood Phe concentration (10-12).

The introduction of newborn screening programs (NBS) represents an important instrument in the secondary prevention of neurological damage caused by PKU. The screening programs must be evaluated systematically, and the results of this evaluation can modify the routine of the service and affect public care management $(13,14)$. The present Brazilian Health Ministry NS policy implemented in 2001 established the University Hospital of the Universidade Federal de Sergipe as the unique center allowed to perform neonatal screening in the State of Sergipe (SE), which is mandatory in the public health care system. Private NBS is not included in governmental statistics of NBS, as this information is not mandatory. SE is the smallest state of Brazil, with the highest gross domestic product of the Northeastern states. We have previously demonstrated that NBS for congenital hypothyroidism in the State of SE had an almost universal coverage, and resulted in an improvement in the time of onset of therapy. Despite of this, we found the need for reducing thyroid stimulating hormone (TSH) cutoff levels to recall suspect cases with less severe cases of congenital hypothyroidism, in order to achieve a full cerebral function (15-17). We do not know if the cutoff levels to recall PKU suspects also needs to change, and if coverage, incidence, and the follow-up of patients with low phenylalanine diet are appropriate.

The aim of this paper is to evaluate both the NBS/ SE for PKU and the dietary care of our followed-up
PKU patients. We thought that these recent data, obtained in Brazil Northeastern region, can be very valuable, especially when Brazilian NBS is expanding with the introduction of new diseases to be screened.

\section{MATERIALS AND METHODS}

A cross-sectional study was conducted in 43,449 children screened by NBS/SE at the University Hospital of Universidade Federal de Sergipe from January 2007 to July 2008. Immediately after collection, heel blood samples were placed on filter paper, and stored in a refrigerator at $4^{\circ} \mathrm{C}$ in the local clinics in all 75 Sergipe municipalities. Transport from all the collection stations occurs daily, with samples at room temperature, to the University Hospital Laboratory in Aracaju. The time between collection and arrival to the laboratory did not exceed 6 hours. Phenylalanine was measured on filter paper (type 903 SS) by an enzymatic colorimetric method (Quantase/Intercientífica, Glasgow, Scotland).

The following parameters were studied: number and age of screened newborns phenylalanine concentrations in different phases of the NBS/SE; its frequency distribution; PKU and hyperphenylalaninemia incidences; and program coverage.

The cutoff for phenylalanine in filter paper, to define suspected PKU children was obtained for a 95\% confidence interval, from all the collected samples, according to the methodology described elsewhere (18-20). The result of phenylalanine in filter paper above the cutoff point was repeated and the average of duplicates was used. Hyperphenylalaninemia was defined a phenylalanine concentration, greater than $5.0 \mathrm{mg} / \mathrm{dL}(2 \mathrm{l})$. Any child with level above this cutoff value is referred to the multiprofessional outpatient clinic of University Hospital for PKU confirmation. Venous blood was obtained and serum Phe was measured in duplicate by an enzymatic colorimetric process. Children are then classified based in venous Phe values (5,21-24) as follows:

A) Children ruled out for PKU: phenylalanine less than or equal to $5.0 \mathrm{mg} / \mathrm{dL}$.

B) Hyperphenylalaninemia: between 5.01 and $10.0 \mathrm{mg} / \mathrm{dL}$.

C) Mild phenylketonuria: between 10.01 and 20.0 $\mathrm{mg} / \mathrm{dL}$.

D) Classical phenylketonuria: greater than $20 \mathrm{mg} / \mathrm{dL}$.

E) Unknown cases: children whose parents did not respond to the recall. 
Monitoring of detected cases was carried out by checking medical records of venous phenylalanine levels over time, the child weight, and daily dietary ingestion of phenylalanine. Metabolic control was defined normal when serum Phe is from 2 to $6 \mathrm{mg} / \mathrm{dL}(22)$.

Student $t$ test was used to compare the cutoffs values of screened children aged 2 to 6 days, and the total of screened children groups. A linear regression model was used to compare the cutoff values of various ages, in the day of collection, from 2 to 30 days. Values of $\mathrm{p}$ less than 0.05 were considered significant. The research was approved by the Research Ethics Committee of the Universidade Federal de Sergipe.

\section{RESULTS}

NBS/SE coverage was $78.93 \%$ in 2007 . The incidence of hyperphenylalaninemia was $1 / 43,449$. The incidence of PKU was $1 / 8,690$. There was one case of mild PKU (20\% of the cases) and four cases of classic PKU $(80 \%$ of the cases). There was one unresolved case, due to the death of the child before the recall $(8.33 \%)$. The highest percentage $(32.36 \%)$ of the screened children had phenylalaninemia levels ranging between 1.01 to
$1.50 \mathrm{mg} / \mathrm{dL}$. The cumulative frequency below $5 \mathrm{mg} /$ $\mathrm{dL}$ was $99.97 \%$ and, therefore, the recall rate was $0.03 \%$ of all screened children. Table 1 shows the frequency distribution for phenylalanine intervals concentration collected in filter paper, and the selected cases above the cutoff value with diagnosis after venous blood measurement.

The mean age of screened children was $9.96 \pm 7.23$ days at the time of filter paper collection; $27.93 \pm 13.08$ days at the time of filter paper assay; and $52.82 \pm 16.95$ days for venous blood collection. The age at the filter paper collection in the PKU cases was $9.80 \pm 8.32$ days, with mean PKUneo concentration of $17.37 \pm 9.16$ $\mathrm{mg} / \mathrm{dL}$ and mean venous phenylalanine concentration of $24.02 \pm 7.26 \mathrm{mg} / \mathrm{dL}$. PKU treatment began within $51 \pm 12$ days of life. Of the 12 PKU suspected cases, four $(33.33 \%)$ had PKUneo greater than $10 \mathrm{mg} / \mathrm{dL}$ and venous phenylalanine concentration higher than $10 \mathrm{mg} / \mathrm{dL}$. Of 8 cases with PKUneo less than or equal to $10 \mathrm{mg} / \mathrm{dL}$, one child with PKUneo of $5.73 \mathrm{mg} / \mathrm{dL}$ had PKU with venous phenylalanine of $20.20 \mathrm{mg} / \mathrm{dL}$. There was one death of a child with PKU confirmed at 90 days of life (age at collection on filter paper: 24 days, PKUneo $16.74 \mathrm{mg} / \mathrm{dL}$, venous phenylalanine 13.30

Table 1. Frequency distribution of phenylalanine filter paper concentration in children of NBS/SE, from January 2007 to June 2008 , with the selected cases above the cutoff value and diagnosis after venous measurement

\begin{tabular}{|c|c|c|c|c|c|c|c|c|c|}
\hline PKUneo mg/dL & $n$ & $\%$ & $\% A$ & Selection & PKUrecall & Discarded & Hyperphenyl & Phenylketonunia & Unknown \\
\hline $0.01-5.00$ & 43,437 & 99,972 & 99,972 & - & - & - & - & - & - \\
\hline 5.73 & 1 & 0.002 & 99,974 & 1 & 20.20 & 0 & 0 & 1 & 0 \\
\hline 5.93 & 1 & 0.002 & 99,977 & 1 & - & 0 & 0 & 0 & 1 death \\
\hline 6.51 & 1 & 0.002 & 99,979 & 1 & 1.80 & 1 & 0 & 0 & 0 \\
\hline 6.58 & 1 & 0.002 & 99,981 & 1 & 2.40 & 1 & 0 & 0 & 0 \\
\hline 6.76 & 1 & 0.002 & 99,984 & 1 & 1.85 & 1 & 0 & 0 & 0 \\
\hline 6.83 & 1 & 0.002 & 99,986 & 1 & 3.05 & 1 & 0 & 0 & 0 \\
\hline 8.10 & 1 & 0.002 & 99,988 & 1 & 8.00 & 0 & 1 & 0 & 0 \\
\hline 9.58 & 1 & 0.002 & 99,990 & 1 & 2.29 & 1 & 0 & 0 & 0 \\
\hline 12.70 & 1 & 0.002 & 99,993 & 1 & 31.60 & 0 & 0 & 1 & 0 \\
\hline 16.74 & 1 & 0.002 & 99,995 & 1 & 13.30 & 0 & 0 & 1 & 0 \\
\hline 21.70 & 1 & 0.002 & 99,997 & 1 & 26.80 & 0 & 0 & 1 & 0 \\
\hline 30.00 & 1 & 0.002 & 100,000 & 1 & 28.15 & 0 & 0 & 1 & 0 \\
\hline Total & 43,449 & 100,000 & - & 12 & - & 5 & 1 & 5 & 1 \\
\hline Selected \% & - & - & - & 100.00 & - & 41.67 & 8.33 & 41.67 & 8.33 \\
\hline Prevalence & - & - & - & 3,621 & - & 8,690 & 43,449 & 8,690 & 43,449 \\
\hline$\%$ screened & - & - & - & 0.028 & - & 0.011 & 0.002 & 0.011 & 0.002 \\
\hline
\end{tabular}


$\mathrm{mg} / \mathrm{dL}$, beginning of treatment 74 days). The cause of death is unknown.

From the 43.449 screened children in the period, only $26.74 \%$ of children were the ideal age $(4.76 \pm$ 1.04 days), between 2 and 6 days of life. There was no difference between PKUneo concentration values in children whose samples were collected between 2 to 6 days and after 6 days $(1.65 \pm 0.65 \mathrm{mg} / \mathrm{dL}$ and $1.59 \pm$ $0.63 \mathrm{mg} / \mathrm{dL}$, respectively).

The biochemical control of the four patients followed up in 2011 was compared with the recommended maximal level of serum Phe $(6 \mathrm{mg} / \mathrm{dL})(22)$ and summarized below:

- Patient code $1: 90.91 \%$ of 11 serum Phe from 125 to 1,288 days old were up to $6 \mathrm{mg} / \mathrm{dL}(16.90 \pm$ $9.06 \mathrm{mg} / \mathrm{dL}$; range: 2.50 to $32.30 \mathrm{mg} / \mathrm{dL}$ ).

- Patient code 2: $9.38 \%$ of 32 serum Phe from 108 to 1,534 days old were up to $6 \mathrm{mg} / \mathrm{dL}$ $(1.89 \pm 3.16 \mathrm{mg} / \mathrm{dL}$; range: 0.01 to 15.25 $\mathrm{mg} / \mathrm{dL})$.

- Patient code 3: $61.11 \%$ of 18 serum Phe from 61 to 1,617 days old were up to $6 \mathrm{mg} / \mathrm{dL}(6.46$ $\pm 2.72 \mathrm{mg} / \mathrm{dL}$; range: 0.70 to $9.70 \mathrm{mg} / \mathrm{dL}$ ).

- Patient code 4: $37.04 \%$ of 27 serum Phe from 63 to 1,298 days old were up to $6 \mathrm{mg} / \mathrm{dL}$ ( 5.76 $\pm 4.67 \mathrm{mg} / \mathrm{dL}$; range: 0.01 to $16.35 \mathrm{mg} / \mathrm{dL})$.

These data were compared with the phenylalanine intake at 9 time points (Table 2). In five moments that the intake of phenylalanine dietary was low, biochemical control was normal in four patients $(80 \%)$, but patient 3 with low Phe intake at 17 months of age had serum Phe of $7.9 \mathrm{mg} / \mathrm{dL}$, indicating inadequate control. In the four moments that the intake of phenylalanine was normal, biochemical control was adequate in only two patients $(50 \%)$, and patient 1 at 11 months of age and patient 2 at 3 months of age had serum Phe concentrations above $6 \mathrm{mg} / \mathrm{dL}(7.5$ and $6.2 \mathrm{mg} / \mathrm{dL}$, respectively), indicating inadequate control.

\section{DISCUSSION}

NBS/SE coverage was $78.93 \%$, in $2007,76.28 \%$ in 2005 and $72 \%$ in 2003 (15-17). This number is indeed higher if we take into consideration that $11 \%$ of coverage done by the private healthcare system (according to data of National Agency of Supplementary Health) is not included in this coverage (16). Regardeless of this, efforts must be made to reach universal coverage. The rate of $10 \%$ of unscreened children is ethically unacceptable.

The incidence of hyperphenylalaninemia was $1 / 43,449 ; 20 \%$ of the suspected cases; similar to what was reported in a French program (25). The incidence of PKU was $1 / 8,690$, halfway between most European (more than 1 in 10,0000) and Arabian countries (up to $\mathrm{l}$ in 5,000$)(1,2)$, and higher than in people of African ancestry (26). Although, the very low incidence seen in Finland ( 1 in 200,000) and Japan ( 1 in 125,000 ) was due to a pronounced negative founder effect in Finland and genetic drift in the founding of the Japanese island population; the high incidence of PKU in Turkey $(1: 2,600)$ was probably due to the high prevalence of consanguinity (2). There was one case of mild PKU (20\% of the cases) and four cases of classic PKU ( $80 \%$ of the cases). These percentages are similar to those found in the neighboring Brazilian state of Bahia (27).

The time blood collection in filter paper (PKUneo) from 2 to 30 days of age did not interfere with the

Table 2. Follow up of subjects with phenylketonuria

\begin{tabular}{lccccc}
\hline Gender code & Month of age & Phe intake & $\begin{array}{c}\text { Recommended } \\
\text { Phe intake }\end{array}$ & $\begin{array}{c}\text { Serum Phe } \\
\text { mg/dL }\end{array}$ & Metabolic control \\
\hline F & 5 & $29.09^{\star}$ & $40 \pm 10$ & 2.5 & Normal \\
1 & 11 & 23.49 & $30 \pm 8$ & 7.5 & Above \\
F & 3 & 41.16 & $58 \pm 18$ & 6.2 & Above \\
2 & 8 & 29.49 & $32 \pm 9$ & 0.65 & Below \\
M & 16 & 24.87 & $30 \pm 8$ & 1.70 & Below \\
3 & 6 & $26.21^{*}$ & $40 \pm 10$ & 3.1 & Normal \\
M & 17 & $30 \pm 8$ & 7.9 & Above \\
4 & 2 & $22.71^{*}$ & $58 \pm 18$ & 5.85 & Normal \\
\hline
\end{tabular}

PKUneo: phenylalanine dosage in filter paper. Phe intake: phenylalanine intake $\mathrm{mg} / \mathrm{kg} /$ weight $/$ day. ${ }^{*}$ Recommended phenylalanine intake (mg/kg/weight) less than a standard deviation (19). Metabolic control is defined normal when serum Phe is from 2 to $6 \mathrm{mg} / \mathrm{dL}(22)$. 
establishment of the cutoff value. In a study with Cuban children (18), 9 showed PKUneo values somehow lower than ours $(1.10 \pm 0.85 \mathrm{mg} / \mathrm{dL})$, suggesting that cutoff levels may have regional variability. A historical paper, using our enzymatic colorimetric process, analyzed 3,800 French children with a cutoff value of 3.5 standard deviations above the mean $(3 \mathrm{mg} / \mathrm{dL})$. They recalled 15 children (recall rate of $0.39 \%$ ) with one PKU case, $6.66 \%$ of children recalled (20). If we had used the cutoff of 3.5 standard deviations above the mean $(4 \mathrm{mg} / \mathrm{dL})$, we would have had a recall rate of $0.287 \%$ ( 125 children). By using the cutoff of 5.0 $\mathrm{mg} / \mathrm{dL}$, our recall rate was $0.028 \%$ (almost eleven times lower than the recall rate of those authors), which represented just 12 children, with five PKU cases and one case of hyperphenylalaninemia. A lower recall rate prevents false-positives cases and causes less anxiety for the families. Although lower cutoffs than ours have been reported $(19,20)$, our recall rate is near the lower inferior limit of those of different programs, ranging from $0.02 \%$ to $0.19 \%(21,22)$, suggesting no need for reduction in PKU cutoffs levels, as we have shown for congenital hypothyroidism (17). One suspected and one confirmed PKU subject died. Unfortunately, we do not know the causes of death in these subjects, but very seldom is PKU lethal (28).

Analyses of biochemical control of our patients reveals that an appropriate phenylalanine intake is not a guarantee of normal biochemical control. This difficult metabolic control obtained despite low Phe diet suggests the need for new treatments, such as medications in liquid form (29), large neutral amino acid supplementation (30), or sapropiterin dihydrochloride (31) to improve compliance and prevent brain development sequels in cognitive function with neurological behavioral problems $(32,33)$. Therefore, both the delayed beginning of treatment and inadequate metabolic control in the follow-up may cause impairment of the quality of life of our PKU individuals. It is interesting that even earlytreated PKU can impair the quality of life, in spite of universal and effective PKU NBS for more than 50 years (34). Therefore, we must continue to address factors that affect patient treatment outcomes, and not just celebrate the prevention of severe mental retardation (35), as obtained by our NBS program.

In conclusion, our program does not provide universal coverage, but its cutoff is adequate for recalling and diagnosis. Nevertheless, the onset of treatment is often delayed, and the follow-up metabolic control is frequently inadequate. Improving NBS effectiveness is desirable to prevent suboptimal cognitive performance, and potential reversible brain lesions. Alternative treatment to the exclusive dietary control can be useful in this scenario.

Disclosure: no potential conflict of interest relevant to this article was reported.

\section{REFERENCES}

1. Loeber JG. Neonatal screening in Europe; the situation in 2004. J Inherit Metab Dis. 2007;30:430-8.

2. Williams RA, Mamotte CDS, Burnett JR. Phenylketonuria: an inborn error of phenylalanine metabolism. Clin Biochem Rev. 2008;29(1):31-41.

3. Birk Møller L, Nygren AO, Scott $P$, Hougaard $P$, Bieber Nielsen J, Hartmann $C$, et al. Low proportion of whole exon deletions causing phenylketonuria in Denmark and Germany. Hum Mutat. 2007;28:207.

4. Feillet F. Phenylketonuria. Presse Med. 2006;35:502-8.

5. Brandalize SRC, Czeresnia D. Evaluation of the program for prevention and health promotion in phenylketonuria patients in Brazil. Rev Saúde Pública. 2004;38:300-6.

6. Dulin IE, Cortés-Casteli E, Chamorro-Ureña F, et al. Estado actual de los programas de cribado neonatal en España. Evaluación año 1999. Acta Pediátr Esp. 2001;59:467-78.

7. Güttler F, Azen C, Guldberg P, Romstad A, Hanley WB, Levy HL, et al. Relationship among genotype, biochemical phenotype, and cognitive performance in females with phenylalanine hydroxylase deficiency. Pediatrics. 1999;104:258-62.

8. Santos LL, Magalhães MC, Januário JN, Aguiar MJB, Carvalho MRS. The time has come: a new scene for PKU treatment. Genet Mol Res. 2006;5:33-44.

9. de Soneville LM, Huijbregts SC, van Spronsen FJ, Verkerk $\mathrm{PH}$, Sergeant JA, Licht R. Event-related potential correlates of selective processing in early - and continuously-treated children with phenylketonuria: effects of concurrent phenylalanine level and dietary control. Mol Genet Metab. 2010;99:10-7.

10. Thompson AJ, Tillotson S, Smith I, Kendall B, Moore SG, Brenton DP. Brain MRI changes in phenylketonuria. Association with dietary status. Brain. 1993;116:811-21.

11. Walter JH, White F, Wraith JE, Jenkins JP, Wilson BP. Complete reversal of moderate/severe brain MRI abnormalities in a patient with classical phenylketonuria. J Inherit Metab Dis. 1997;20:367-9.

12. Cleary MA, Walter JH, Wraith JE, White F, Tyler K, Jenkins JP. Magnetic resonance imaging in phenylketonuria: reversal of cerebral white matter change. J Pediatr. 1995;127:251-5.

13. Ardaillou R, Le Gall JY. Mass neonatal screening using biological testing. Gynecol Obstet Fertil. 2007;35:367-74.

14. Cornejo V, Raimann E, Cabello JF, Valiente A, Becerra C, Opazo M, et al. Past, present and future of newborn screening in Chile. $J$ Inherit Metab Dis. 2010;33 Suppl 3:S301-6.

15. Ramalho RJR, Valido DP, Aguiar-Oliveira MH. Avaliação do Programa de Triagem para o Hipotireoidismo Congênito no Estado de Sergipe. Arq Bras Endocrinol Metab. 2000;44:157-61.

16. Ramalho RJR, Ramalho ARO, Oliveira CRP, Aguiar-Oliveira MHA. Evolução do Programa de Triagem Neonatal para o Hipotireoidismo Congênito e Fenilcetonúria no Estado de Sergipe de 1995 a 2003. Arq Bras Endocrinol Metab. 2004;48:890-6.

17. Ramalho ARO, Ramalho RJR, Oliveira CRP, Santos EG, Oliveira MCP, Aguiar-Oliveira MH. Programa de Triagem Neonatal para 
Hipotireoidismo Congênito no Nordeste do Brasil: Critérios Diagnósticos e Resultados. Arq Bras Endocrinol Metab. 2008;52:617-27.

18. Marrero-Gonzalez N, Frómeta-Suarez A, Gonzalez-Reyes E, et al. Cribado neonatal piloto para hipotiroidismo congénito fenilcetonuria, galactosemia y deficiencia de biotinidasa. Rev Esp Pediatr. 2002;58:356-62.

19. Schulz A, Mayatepek E, Hoffman GF. Evaluation of six year application of the enzymatic colorimetric phenylalanine assay in the setting of neonatal screening for phenylketonuria. Clin Chim Acta. 2002;317:27-37.

20. Dhont JL, Paux E. Evaluation of an enzymatic colorimetric method for the neonatal screening of phenylketonuria. Screening. 1993;2:141-7.

21. Koch RK. Issues in newborn screening for phenylketonuria. Am Fam Physician. 1999;60:1462-6.

22. Sinai LN, Kim SC, Casey R, Pinto-Martin JA. Phenylketonuria screening: effect of early newborn discharge. Pediatrics. 1995;96:605-8.

23. Papendieck LG, Chiesa A, Prieto L, Bergada C. Prevención secundaria de errores congênitos del metabolismo: pesquisa neonatal. A.N. de Medicina. 1998;76:477-97.

24. Michele A, Lloyd-Puryear-Therrell BL. Screening Procedures: Variations in Diagnostic Criteria and Follow up, In: Consensus Development Conference on Phenylketonuria (PKU): screening and management. Maryland, United States; 2000. p. 37-40.

25. Baulny HO, AbadieV, Feillet F, Parscan L. Management of phenylketonuria and hyperphenylalaninemia. J Nutr. 2007;137:1561-3.

26. Hardelid $P$, Cortina-Borja $M$, Munro $A$, Jones $H$, Cleary $M$, Champion MP, et al. The birth prevalence of PKU in populations of
European, South Asian and sub-Saharan African ancestry living in South East England. Ann Hum Genet. 2008;72:65-71.

27. Amorim T, Gatto SPP, Boa-Sorte N, Leite MEQ, Fontes MIMM, Barretto J, et al. Aspectos clínicos da fenilcetonúria em serviço de referência em triagem neonatal da Bahia. Rev Bras Saude Mater Infant. 2005;5:457-62.

28. Watson BM, Schlesinger P, Cotton RG. Dihydroxanthopterinuria in phenylketonuria and lethal hyperphenylalaninemia patients. Clin Chim Acta. 1977;78(3):417-23.

29. MacDonald A, Lilburn M, Davies P, Evans S, Daly A, Hall SK, et al. Ready to drink protein substitute is easier is for people with Phenylketonuria. J Inherit Metab Dis. 2006;29:526-31.

30. Matalon R, Surendran S, Matalon KM, Tyring S, Quast M, Jinga $W$, et al. Future role of large neutral amino acids in transport of phenylalanine into the brain. Pediatrics. 2003;112:1570-4.

31. Gassió R, Vilaseca MA, Lambruschini N, Boix C, Fuste ME, Campistol J. Cognitive functions in patients with phenylketonuria in long-term treatment with tetrahydrobiopterin. Mol Genet Metab. 2010;99:S75-8.

32. Berry HK, O'Grady DJ, Perlmutter LJ, Bofinger MK. Intellectual development and academic achievement of children treated early for phenylketonuria. Dev Med Child Neurol. 1979;21:311-20.

33. Koff E, Boyle P, Pueschel SN. Perceptual-motor functioning in children with phenylketonuria. Am J Dis Child. 1977;131:1084-7.

34. White DA, Waishbren S, van Spronsen FJ. Final commentary: a new chapter. Mol Genet Metab. 2010;99:S106-7.

35. Berry SA, Brown C, Grant M, Greene CL, Jurecki E, Koch J, et al. Newborn screening 50 years: access issues faced by adults with PKU. Genet Med. 2013;15(8):591-9. 